\title{
How can an infaunal brooding echinoid be maintained in the laboratory? A case study with Cassidulus mitis (Echinoidea: Cassiduloida)
}

\author{
Carlos Renato Rezende Ventura ${ }^{1 *}$ \\ Monalisa Sousa Pinto de Oliveira ${ }^{1}$
}

1. Museu Nacional, Universidade Federal do Rio de Janeiro. Departamento de Invertebrados, Laboratório de Echinodermata.rventura@mn.ufrj.br (*Correspondence),monalisasousapinto2009@hotmail.com

Received 01-IX-2020. Corrected 20-X-2020. Accepted 28-XI-2020.

\begin{abstract}
Introduction: Cassiduloids play a prominent role in echinoid evolutionary history because they probably are the ancestral group of clypeasteroids. Some extant species are brooding and rare in the environment. Consequently, there are no studies on their maintenance in the laboratory. Objective: Establish an efficient aquarium system for $C$. mitis, endemic to Brazil, for ontogenetic studies. Methods: Four aquarium systems were built, with 3 replicates each one: (1) with seawater flow [F]; (2) with seawater flow and air injection into sediment [FA]; (3) without seawater flow but with air injection into the sediment [A]; and (4) without both seawater flow and air injection into the sediment [C]. Each experimental aquarium (three per treatment) had two adults. Each of the two sets of experiments lasted about 60 days. Results: We observed low mortality in the first 30 days in all systems and, after 30 days, it was higher in those with air-pumped into the sediment (system A in the first set of experiments, and system FA in the second one). Conclusions: For experiments lasting 30 days, our four systems are suitable. For longer periods, we recommend aquaria with seawater flow and without air-pumps into the sediment.
\end{abstract}

Key words: experimental model-species, closed aquarium system, survival rate, sand-bottom, echinoid deposit feeder.

In general, brooding marine invertebrates have a rapid direct development or an abbreviate indirect development with a non-feeding larval stage followed by a quick metamorphosis. In particular, echinoderms have these patterns and are recognized as useful models for studies on embryology, life history, evolution, and development (Evo-Devo), among other fields of knowledge (Raff \& Byrne, 2006; Heyland, Schuh \& Rast, 2018). However, it is not easy to find coastal marine species considered that are suitable good experimental models. The most significant difficulties are their availability in the field and their maintenance in the laboratory for enough time to record valuable changes in morphology.

The echinoid Cassidulus mitis Krau, 1954, belongs to the order Cassiduloida Claus, 1880, which comprises about 68 genera and 800 species, most of them extinct (Mooi, 1990a; Kroh \& Mooi, 2020). The first records of cassiduloids appear in the Lower Jurassic (about 200 m.y.a). This order reached its highest diversity in Eocene (about 55 m.y.a.) when it represented $60 \%$ of all echinoids (Kier, 1962). The decline of cassiduloids occurred between the Late Tertiary and Quaternary (about 30 m.y.a.). This diversity drop was probably related to 
global cooling and the increase of competition with other echinoids. The decline of cassiduloids coincided with the rise of the sand dollars (Clyperasteroida) and heart urchins (Spatangoida), considered as sister-groups. The fossil records corroborate the hypothesis of competition, causing the diversity decrease of cassiduloids. Mooi (1990a) states that there are 30 extant species within the order Cassiduloida. The morphological similarity between the fossil and extant species is evident (Brito \& Ramires, 1974; Brito, 1981; Smith \& Bengston, 1991; Squires \& Demetrion, 1995), which means that extant cassiduloids have a highly conserved morphology. In other words, no significant morphological novelty has occurred along their lineage since the Upper Cretacean (Smith, 2001). Therefore, the extant species show signs of "character exhaustion," as defined by Wagner (2000). For these reasons, the cassiduloids fit in the concept of "living fossil" (Schopf, 1984; Mooi, 1990b).

Cassiduloids play a prominent role in echinoids' evolutionary history because they probably are the ancestral group of the sand dollar lineage (clypeasteroids). Among all echinoids, the species of Cassiduloida are unique that have the Aristotle's lantern only during the early young stage (post-metamorphosis). The morphological similarity between the lanterns of small cassiduloids and large clypeasteroids is the primary support for this hypothesis. In other words, the retention of ancestral young characters in the adult descendant species (neoteny) supports this hypothesis. Despite its evolutionary relevance, the loss of the Aristotle's lantern of extant cassiduloids still has not been well-studied (Gladfelter, 1978; Märkel, 1978; Contins \& Ventura, 2011). The principal cause for this knowledge gap is the difficulty of finding dense populations in the field and the ability to maintain cassiduloids in the laboratory for enough time to record all significant morphological changes during the loss of Aristotle's lantern. The best way to keep young post-metamorphic cassiduloids alive is on adult females, among their spines.
Therefore, the maintenance of adults in the laboratory is crucial.

Cassidulus mitis is an endemic infaunal species from Brazil (Tommasi \& Lima-Verde, 1970). It occurs in a relatively high abundance in one locality, and it has a continuous reproductive cycle, develops yolky eggs, embryos, and lecithotrophic larvae. Cassidulus mitis broods its offspring among the female spines for 18 days, when the post-metamorphic juveniles (that have the Aristotle's lantern) leave their parent to the coarse-sandy environment (MacCord \& Ventura, 2004; Contins \& Ventura, 2011). After this period, juveniles continue their development, assuming an ellipsoidal shape, and lose their lantern. As adults, they start to consume the organic matter from the sediment.

Therefore, Cassidulus mitis is a crucial species of evolutionary relevance. Some previous studies have already gathered important information about its biology. Its ready availability in a coastal area gives it the potential to be a good species model. However, it is still necessary to establish methods to keep it in the laboratory. This study aims to establish an efficient aquarium system to maintain $C$. mitis in laboratory conditions for enough time for developmental studies.

\section{MATERIALS AND METHODS}

\section{Study Area}

The population of $C$. mitis occurs at the beach Praia Vermelha (22 $57^{\circ}$ ' $18^{\prime \prime} \mathrm{S}$; $43^{\circ}$ 9' 48' W) located at the entrance of the Guanabara Bay (Rio de Janeiro State, Brazil). It is a short beach with a sharp decline in the bottom caused by waves and periodic storms. The substrate at the Praia Vermelha consists of homogeneous coarse sand of rounded grains of quartz (Freire, Santos, Fontoura, Magalhães \& Grohamann, 1992). The climate in this region is typically tropical, warm, and rainy, with two distinct seasons, dry in autumn and winter, and rainy in spring and summer. 


\section{Collection of specimens, seawater, and sediment}

Specimens of $C$. mitis were collected from the infralittoral zone at depths between 2 and 4 meters by apnea free-diving in May and August 2019. The temperature of the seawater was about $22^{\circ} \mathrm{C}$. The salinity was about $35 \mathrm{ppm}$. We collected seawater and sediment just after the collection of the sea urchins.

\section{Aquarium systems, monitoring of survival, seawater temperature, and salinity}

Adult sea urchins were kept in four aquarium systems, simulating somewhat of natural conditions. These were four sets of experimental aquaria (plastic box of $33.5 \mathrm{~cm} \times 24,0 \mathrm{~cm}$ $\mathrm{x} 16,0 \mathrm{~cm}$ ) with seawater and a layer of $5 \mathrm{~cm}$ of sediment from the Praia Vermelha. Each system had one treatment with three replicates: (1) Aquaria with seawater flow - $[\mathrm{F}]$; (2) Aquaria with seawater flow and air-pumped into the sediment bottom - [FA]; (3) Aquaria without seawater flow and with air-pumped into the sediment - [A]; and (4) Aquaria without both seawater flow and air-pumped into

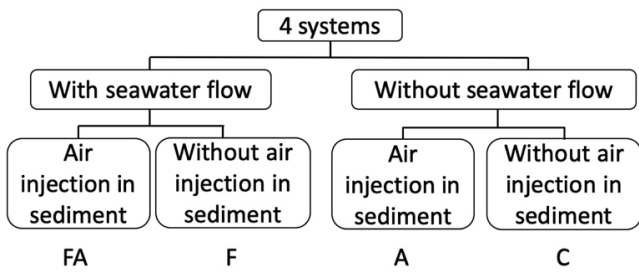

Fig. 1. Experimental design of the four aquarium systems. (FA) Aquaria with seawater flow and air-pumped in sediment bottom; (F) Aquaria with seawater flow; (A) Aquaria without seawater flow and with air-pumped in the sediment; and (C) Aquaria without both seawater flow and air-pumped in sediment.

the sediment $-[\mathrm{C}]$ (Fig. 1 and Fig. 2). The air into sediment was provided by an air-pump connected to porous-stone sticks (12 cm long) buried in each aquarium's sediment layer. Each experimental aquarium had two adults (a total of 12 females and 12 males, ranging from $2.2 \mathrm{~cm}$ to $4.6 \mathrm{~cm}$ and $2.2 \mathrm{~cm}$ to $3.9 \mathrm{~cm}$ of the longest test diameter, respectively). Sexual differences in $C$. mitis can be distinguished by their dimorphic genital papillae in the apical region of the test (Tripneustes-type papillae) (Tahara, Okada \& Kobayashi, 1958;

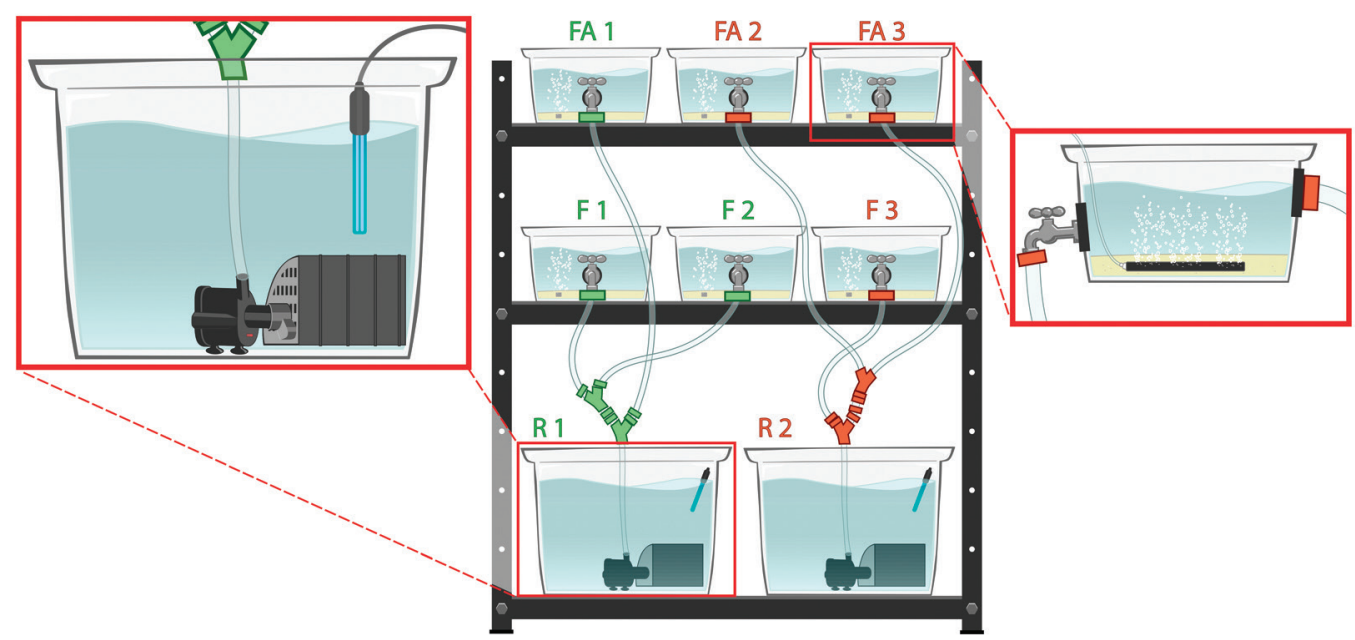

Fig. 2. Arrangement of the four experimental aquarium systems. A - Aquaria with seawater flow and air-pumped into the sediment (FA); Aquaria with seawater flow (F); Aquaria without seawater flow and with air-pumped into the sediment (A); Aquaria without both seawater flow and air-pumped into the sediment (C); Tanks (30L) (R). Numbers $(1,2,3)$ represent replicates in each treatment. B - A single flow-aquarium system. Immersed pump (P); Filters (F). Arrows represent the flow directions. Aquaria systems developed by Renato R. Ventura. 
Pearse \& Cameron, 1991). These experimental aquaria systems are original and were developed by Carlos Renato R. Ventura.

The seawater was filtered in all treatments. Filters of the two flowing systems (F and FA) cleaned seawater in tanks (30L). Seawater came to tanks from aquaria by gravitation force and returned to each aquarium by immersed pumps (Fig. 2). These filters had three layers that provide mechanical (with synthetic polyamide fibers), chemical (with charcoal), and biochemical filtration (with ceramic rings). Seawater flow was supplied by immersed pumps (with the flow rate of 400 to $1000 \mathrm{~L} / \mathrm{h}$ ) connected to each tank's filters. The average seawater flow speed in experimental aquaria was $5.11 \mathrm{~cm} / \mathrm{s}( \pm 1.19,1 \mathrm{SD})$. In two other systems without seawater flow (A and C), filters were inside each aquarium. Because each aquarium had a smaller seawater volume (4L) in these cases, a single biochemical filter at the bottom was sufficient to keep the water clean.

Each aquarium was monitored daily during the first week and twice a week along with the experiments, checking sea urchin survival, and measuring seawater temperature and salinity. Two sets of experiments were performed. Each of them lasted about 60 days.

The mean seawater temperature was $23.8^{\circ} \mathrm{C}$ \pm 1.9 (mean \pm 1 standard deviation). Salinity was corrected when it was over $35 \mathrm{ppm}$.

The staff of the Unit of Environmental Analysis (UFRJ) analyzed the substrate using the granulometric laser diffraction method. They also measured the percentage of organic matter in the substrate by the calcination method. We took one sediment sample before distributing it in each aquarium, at the beginning of each set of the experiment (initial), and other sediment samples from each aquarium of all treatments at the end of experiments (final samples).

\section{Statistical Analyses}

We used the Kaplan-Meier Method, the Log-Rank test (Krebs, 2017), and the ANOVA
Linear Mixed Model to compare statistical differences of the survival rates of $C$. mitis in the four aquarium systems for the two sets of experiments (May and August 2019). We used the R Program (The R Project for Statistical Computing, <www.r-project.org $>$ ) to perform all analyses.

\section{RESULTS}

The two sets of experiments lasted about 60 days. Survival rates in the four experimental aquaria systems were higher than $50 \%$ after the first 30 days in both sets of experiments, except for the FA system of the second group (Fig. 3 and Fig. 4). Most of the variation occurred after this time $\left(30^{\text {th }}\right.$ day). It was statistically significant in those systems with air-pumped into the sediment (system $\mathrm{A}$ in the first set of experiments, and system FA in the second one) (Fig. 3 and Fig. 4). The death of sea urchins occurred independently of their size. Two brooding females $(3.4 \mathrm{~cm}$ and $4.9 \mathrm{~cm}$ in longest diameter) were tested in the second set of experiments.

The ANOVA Linear Mixed Model corroborated the Kaplan-Meier and Log-rank analyses. ANOVA results show that a significant variation of survival rates occurred as a function of time for both sets of experiments for all aquarium systems. Also, ANOVA identified significant deviation from the system $\mathrm{C}$ (Control) of treatment $\mathrm{A}$ in the first group and the treatment FA in the second set of experiments (Supplementary Material).

Granulometric analyses classified the sediment as coarse sand and moderately sorted, confirming the previous studies at Praia Vermelha. The content of organic matter in the initial sediment sample of each set of experiments was very different. It was much lower in the first group than in the second one (Fig. 5). The highest organic matter contents in the sediment occurred in system $\mathrm{F}$ at the end of the experimental period in both sets of experiments (Fig. 5). 

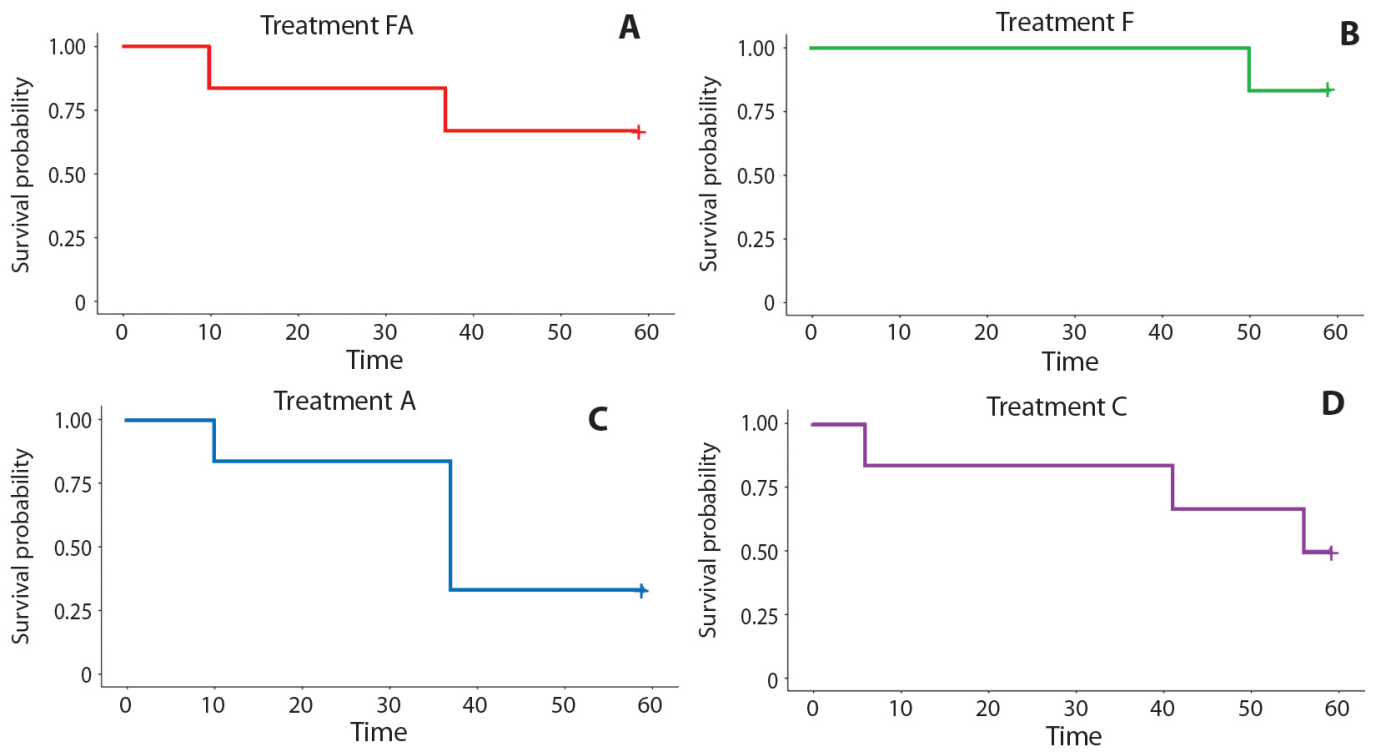

Fig. 3. Cassidulus mitis. Kaplan-Meier survival analysis and Log-Rank test $(\mathrm{P}=0.31)$ for the first set of experiments.
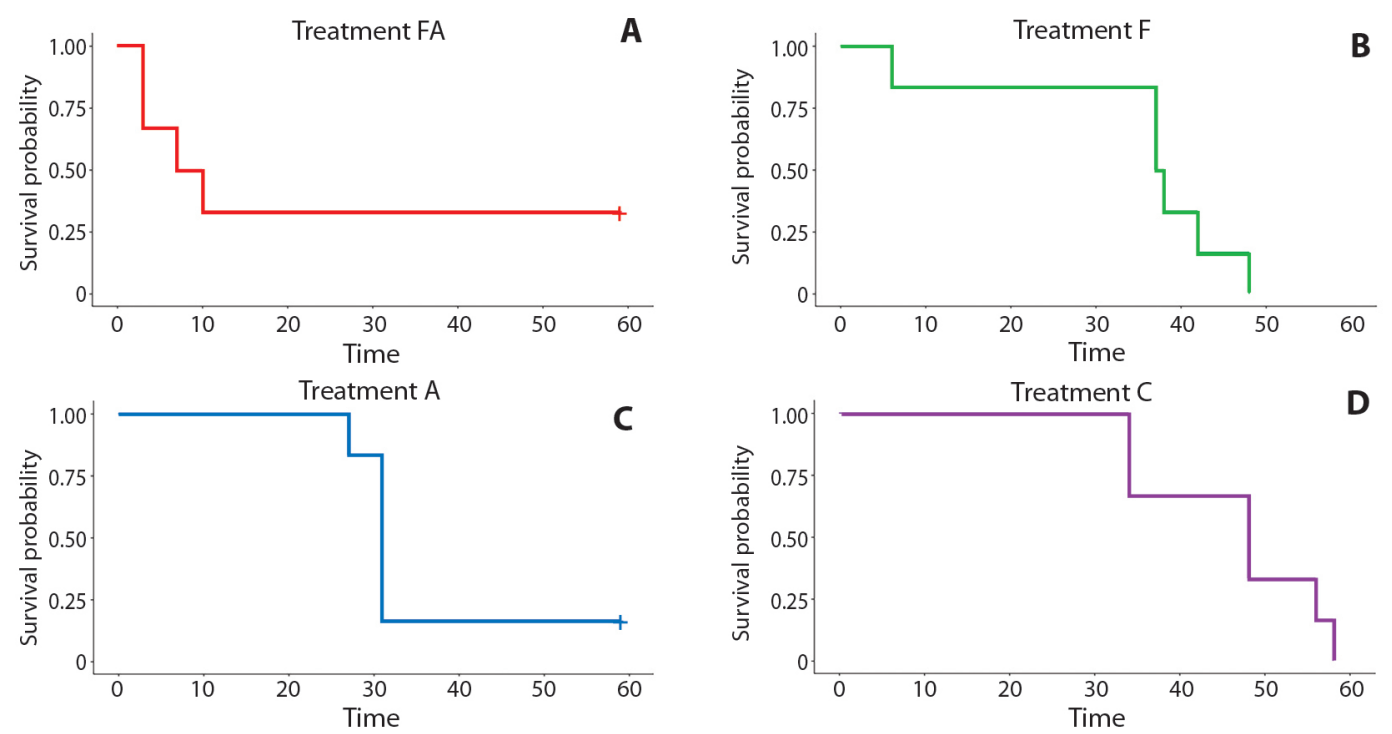

Fig. 4. Cassidulus mitis. Kaplan-Meier survival analysis and Log-Rank test $(\mathrm{P}=0.85)$ for the second set of experiments. 


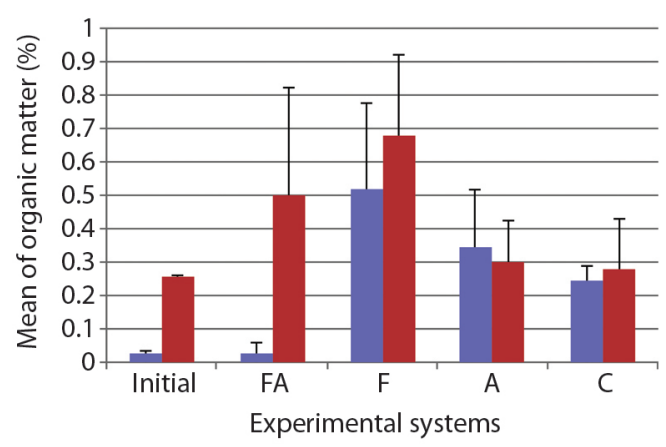

Fig. 5. Mean content of organic matter in the sediment of initial samples and each of four treatments. Blue bars $=$ First set of experiments; Red bars $=$ Second set of experiments. Variation bars $=$ Standard deviation.

\section{DISCUSSION}

Like other infaunal echinoderms, Cassidulus mitis consumes sediment, ingesting the organic matter associated with the grains. Although the feeding mechanism of $C$. mitis is not well-described, it probably is similar to that of Cassidulus caribaearum Lamarck, 1801. It uses special podia (phyllopodia and accessory podia) to gather and handle coarse sand grains with no obvious selection for particles (Gladfelter, 1978; Telford \& Mooi, 1996). Both species of Cassidulus live in reflective beaches, burrowed in coarse sand between the first layers $(3-5 \mathrm{~cm})$ and $20 \mathrm{~cm}$ below the bottom surface (Gladfelter, 1978; C.R.R. Ventura, personal observation). On beaches with a predominantly reflective system (like Praia Vermelha), bottom currents play a relevant role in sediment dynamics. Rip currents, incidental storms, and reflected waves can stir up surface layers of the bottom, providing oxygen supply, bringing and taking organic matter from the substrate. Therefore, the ability to obtain food (organic matter) and oxygen and to maintain position within the substrate is essential for well-being and survival in such an environment. Being a sand-ingesting deposit feeder, $C$. mitis (and probably C. caribaearum) keeps its gut full of sediment all time (C.R.R. Ventura, personal observation) to obtain energy and enough weight warranting stability against bottom current effects.
The experimental design in this study focused on simulating somewhat similar natural conditions in the aquarium systems, evaluating the combined and isolated effects of bottom current and air-stirring substrate in the survival of $C$. mitis. The duration of the experiments and the contents of organic matter into the sediment seem to be the principal factors that influence the survival of $C$. mitis under laboratory conditions. The four treatments are similarly efficient during the first 30 days, but they gradually lose efficiency in the subsequent days. Probably, variation in organic matter contents in the sediment over time caused mortality after the first month. As an alternative solution, we propose to replace the sand of all aquaria with a recently collected substrate from the sample site. However, we emphasize that organic matter contents in sediment can vary greatly in a reflective beach, spatially and temporally. In this study, the initial substrate samples of the two sets of experiments varied significantly.

The oxygen concentration in interstitial seawater is also a significant factor in the survival of infaunal sea urchins. Some individuals of $C$. mitis emerged from the sediment showing hypoactivity and died after a few hours. Probably, the low concentration of oxygen in interstitial seawater caused death. Unfortunately, the oxygen concentration in interstitial seawater was not measured, and the cause of deaths can only be suggested. Gladfelter (1978) described the same behavior for $C$. caribaearum after 24 to 36 hours in the laboratory. As the aquarium's oxygen concentration was low $\left(2.13 \mathrm{~mL} \mathrm{O}_{2}\right.$. $\left.\mathrm{L}^{-1}\right)$ at that time, Gladfelter (1978) suggested that the emergence of urchins occurred due to hypoxia. He stated that the oxygen consumption of $C$. caribaearum ranges from 10.2 to $23.3 \mu \mathrm{L} \mathrm{O}_{2}$ g wet weight ${ }^{-1}$. $\mathrm{h}^{-1}$, varying with the weight. Also, he showed experimentally that respiration per unit of weight is higher in smaller sea urchins. There are no data on oxygen consumption of $C$. mitis, and for this reason, the respiration rate of $C$. caribaearum is the best reference. Injection of air into the sediment presumably could increase the concentration of $\mathrm{O}_{2}$ in the interstitial seawater. 
However, the highest mortality rates occurred in those aquaria with air-pumped into the substrate (treatments A and FA). The bubbles of air within the sediment might increase the oxygen concentration but also might remove the organic matter to the water column. It seems to be most crucial to the survival of sea urchins.

In conclusion, the best aquarium systems to maintain $C$. mitis alive in the laboratory for a long time (about 60 days) are those without air-pumped into the sediment and with seawater flow (F), and without both flow and air-pumped in the sediment (C). For short-term experiments (30 days or less), all four systems seem to be suitable. In both cases, monitoring the organic matter in sediment is the best way to determine when the sediment should be replaced.

Ethical statement: authors declare that they all agree with this publication and made significant contributions; that there is no conflict of interest of any kind; and that we followed all pertinent ethical and legal procedures and requirements. All financial sources are fully and clearly stated in the acknowledgements section. A signed document has been filed in the journal archives.

\section{ACKNOWLEDGMENTS}

We are thankful to Dr. Gisela Mandali and Dr. Vinicius Peruzzi (Department of Marine Biology, UFRJ) for all facilities provided in laboratory and sediment analyses, to Dr. Paulo Cesar de Paiva (Department of Zoology, UFRJ) for statistical assistance, and to Dr. Pablo E. Meretta for revising the Spanish Abstract. We are also very grateful to Dr. John Lawrence and three reviewers for their critical comments and suggestions that improved this article. CRRV is thankful to the Fundação Carlos Chagas Filho de Amparo à Pesquisa do Estado do Rio de Janeiro for the research grant (Emergency Support to the Museu Nacional, ref. 242060), and the Conselho Nacional de Desenvolvimento Científico e Tecnológico (CNPq) for the research grant (ref. 310167/2018-3).

\section{RESUMEN}

¿Cómo se puede mantener un equinoide infantil en el laboratorio? Un estudio de caso con Cassidulus mitis (Echinoidea: Cassiduloida)

Introducción: Los casiduloides desempeñan un papel destacado en la historia evolutiva de los equinoides porque probablemente son el grupo ancestral de clipeasteroides. Algunas especies existentes son inquietantes y raras en el medio ambiente. En consecuencia, no existen estudios sobre su mantenimiento en laboratorio. Objetivo: Establecer un sistema de acuario eficiente para C. mitis, endémica de Brasil, para estudios ontogenéticos. Métodos: Se construyeron cuatro sistemas de acuarios, con 3 réplicas cada uno: (1) con flujo de agua de mar [F]; (2) con flujo de agua de mar e inyección de aire en el sedimento [FA]; (3) sin flujo de agua de mar pero con inyección de aire en el sedimento [A]; y (4) sin flujo de agua de mar ni inyección de aire en el sedimento [C]. Cada acuario experimental (tres por tratamiento) tenía dos adultos. Cada uno de los dos conjuntos de experimentos duró aproximadamente 60 días. Resultados: Observamos una baja mortalidad en los primeros 30 días en todos los sistemas y, después de 30 días, fue mayor en aquellos con aire bombeado al sedimento (sistema A en el primer conjunto de experimentos y sistema FA en el segundo). Conclusiones: Para experimentos de 30 días, nuestros cuatro sistemas son adecuados. Para períodos más largos, recomendamos acuarios con flujo de agua de mar y sin bombas de aire en el sedimento.

Palabras clave: modelo-especie experimental, sistema de acuario cerrado, tasa de supervivencia, fondo de arena, depósito alimentador de equinoides.

\section{REFERENCES}

Brito, I.M. (1981). Equinoides fósseis do Brasil II - os holectipoides e cassiduloides. Anais da Acadêmia Brasileira de Ciências. 53(3), 513-527.

Brito, I.M. \& Ramires, L.V. (1974). Contribuição ao conhecimento dos equinoides albianos (Cretáceo Inferior) do Brasil. Anais da Acadêmia Brasileira de Ciências. 46(2), 275-282.

Claus, C. F.W. 1880. Grundzüge der Zoologie. 4th edition. N. G. Elwertsche Universit"atsbuchhandlung, Marburg \& Leipzig, vol. 1, vii +821 pp., vol. 2, iv $+522 \mathrm{pp}$

Contins, M. \& Ventura, C.R.R. (2011). Embryonic, larval, and post-metamorphic development of the sea urchin Cassidulus mitis (Echinoidea; Cassiduloida): An endemic brooding species from Rio de Janeiro, Brazil. Marine Biology, 158(10), 2279-2288.

Freire, C.A.; Santos, P.J.P.; Fontoura, N.F.; Magalhães, R.A.O. \& Grohmann, P.A. (1992). Growth and spatial 
distribution of Cassidulus mitis (Echinodermata: Echinoidea) on a sandy beach in Southeastern Brazil. Marine Biology, (112), 625-630.

Gladfelter, W.B. (1978). General ecology of the cassiduloid urchin Cassidulus caribbearum (sic). Marine Biology, 47(2): 149-160.

Heyland, A., Schuh, N. \& Rast, J. (2018). Sea urchin larvae as a model for postembryonic development. Chapter 8. In: Kloc, M. \& Kubiak, J. Z. (Eds), Marine organisms as model systems in Biology and Medicine. (pp 137-161). Springer, Gewerbestrass, Switzerland. $624 \mathrm{p}$.

Kier, P.M. (1962). Revision of the cassiduloid echinoids. Smithsonian Miscellaneous Collections, 114(3), $1262 \mathrm{p}$.

Krau, L. (1954). Nova espécie de ouriço-do-mar: Cassidulus mitis, ordem Cassiduloida, Echinoidea, capturado na Baía de Sepetiba. Memórias do Instituto Oswaldo Cruz, (52), 455-475.

Krebs, C. (2017). Estimation of survival rates. In: Benjamin Cummings (Ed) Ecological Methodology (pp. 655-698). Chapter 15. 3rd edition, University of California, $768 \mathrm{p}$.

Kroh, A. \& Mooi, R. (2020). World Echinoidea Database. Cassidulus Lamarck, 1801. Accessed through: World Register of Marine Species at http://www.marinespecies.org/aphia.php? $\mathrm{p}=$ taxdetails $\& \mathrm{id}=512626$ on 2020-08-29

Lamarck, J. B. (1801). Système des animaux sans vertèbres, ou tableau général des classes, des ordres et des genres de ces animaux; Présentant leurs caractères essentiels et leur distribution, d'après la considération de leurs rapports naturels et de leur organisation, et suivant l'arrangement établi dans les galeries du Muséum d'Histoire Naturelle, parmi leurs dépouilles conservées; Précédé du discours d'ouverture du Cours de Zoologie, donné dans le Muséum National d'Histoire Naturelle l'an 8 de la République. Published by the author and Deterville, Paris: viii $+432 \mathrm{pp}$.

MacCord, F. S. \& Ventura, C. R. R. (2004). Reproductive cycle of the endemic cassiduloid Cassidulus mitis (Echinoidea: Cassiduloida) on the Brazilian coast. Marine Biology, (145): 603-612.

Märkel, K. (1978). On the teeth of the recent Cassiduloid Echinolampas depressa Gray, and on some Liassic fossil teeth nearly identical in structure (Echinodermata, Echinoidea). Zoomorphologie, (89), 125-144.
Mooi, R. (1990a). Living cassiduloids (Echinodermata: Echinoidea): a key and annotated list. Proceedings of the Biological Society of Washington, 103(1). 63-85.

Mooi, R. (1990b). A new "living fossil" echinoid (Echinodermata) and the ecology and paleobiology of Caribbean cassiduloids. Bulletin of Marine Science, 46(3), 688-700.

Mortensen, T. (1948). Holectypoida, Cassiduloida In: T. Mortensen, A Monography of the Echinoidea 4(1) C.A. Reitzel, Copenhagen, $371 \mathrm{p}$.

Pearse, J.S. \& Cameron, R.A. (1991) Echinodermata: Echinoidea. In: A. C. Giese, J.S. Pearse \& V. B. Pearse. Reproduction in Marine Invertebrates. Vol. VI. Echinoderms and Lophophorates. Chapter 7. 513-662 p. The Boxwood Press, Pacific Groove, California, 808 p.

Raff, R. A. \& Byrne, M. (2006). The active evolutionary lives of echinoderm larvae. Heredity, (97),244-252.

Schopf, T.J.M. (1984). Rates of evolution and the notion of "living fossil". Annual Review of Earth and Planetary Science, (12), 245-292.

Smith, A. B. (2001). Probing the cassiduloid origins of clypeasteroid echinoids using stratigraphically restricted parsimony analysis. Paleobiology, (27),392-404.

Smith, A. B. \& Bengston, P. (1991). Cretaceous echinoids from north-eastern Brazil. Fossils and Strata. (31):1-88

Squires, R.L. \& Demetrion, R.A. (1995). A new genus of cassiduloid echinoid from the Lower Eocene of the Pacific Coast of Western North America and a new report of Cassidulus ellipticus Kew, 1920, from the Lower Eocene of Baja California Sur, Mexico. Journal of Paleontology, 69(3), 509-515.

Tahara, Y., Okada, M. \& Kobayashi, N. (1958) Secondary sexual characters I Japanese sea-urchins. Publications of the Seto Marine Biological Laboratory, 8: 183-189.

Telford, M. \& Mooi, R. (1996). Podial particle picking in Cassidulus caribaearum (Echinodermata: Echinoidea) and the Phylogeny of sea urchin feeding mechanisms. Biological Bulletin, (191), 209-223.

Tommasi, L.R. \& Lima-Verde, J.S. (1970). Observações sobre Cassidulus mitis Krau, 1960 (Cassiduloida, Echinoidea). Boletim do Instituto Oceanográfico. Universidade de São Paulo, 18(1), 1-9.

Wagner, P.J. (2000). Exhaustion of morphologic character states among fossil taxa. Evolution (54), 365-386.

See Digital Appendix at: / Ver Apéndice digital en: revistas.ucr.ac.cr 